\title{
THE ROLE OF GENERAL EDMUND TACZANOWSKI IN CREATING POLAND'S NATIONAL SECURITY
}

\section{Original article}

Autor(s) CC BY 4.0 Licence

Peer review:

Double blind

Keywords:

Edmund Taczanowski, Greater Poland Uprising 1918-1919, January Uprising

\author{
Magdalena Giebułtowska ${ }^{1}$ \\ War Studies University, \\ Al. gen. Antoniego Chruściela "Montera" 103, 00-910
Warszawa
}

Abstract

The person of General Edmund Taczanowski is not widely known and quoted in the bibliography of the subject. He didn't have a direct impact on the fate of the Polish state. However, his person played an important role in the course of the Greater Poland Uprising 1918-1919 and the January Uprising. During January Uprising his deeds went down in Polish history. And even though the Uprising fell, the activity of General Edmund Taczanowski testifies to his patriotic attitude and the will to fight for the Polish state. The goal of this article is an attempt to evaluate the actions taken by Edmund Taczanowski for the Polish state. In the first place, define what heroic deeds were his participation and then evaluate them. This assessment should state how Edmund Taczanowski's activity contributed to the creation of national security of the state. The analysis of the heroic deeds of General Edmund Taczanowski testifies to the fact that he contributed to the creation of Poland's national security.

\footnotetext{
${ }^{1}$ Magdalena Giebułtowska - PhD student in War Studies University, Faculty of National Security; giebultowska.m@gmail.com
} 
An analysis of the heroic deeds of General Edmund Taczanowski demonstrates that he contributed to the creation of Poland's national security.

\section{Introduction}

Polish national security throughout history has been shaped by the actions of many people, who can be surely described as heroes and patriots. Among these people are historic figures, such as Tadeusz Kościuszko ${ }^{2}$, Ignacy Jan Paderewski ${ }^{3}$ and Marshal Józef Piłsudski ${ }^{4}$. Nevertheless, there are also numerous people who, despite their heroic deeds in the name of their homeland, have not been remembered in the historical record. It would seem that their activity, which was largely local, did not have a significant impact on the creation of the country's national security. However, their actions, exerting a significant influence on the fate of local communities, also shaped the national security of the state, at least to some extent. Local communities, which were direct witnesses of such people's actions, often made them into icons ${ }^{5}$. It is also worth recalling here the words of Aleksander Kamiński, according to whom the power of the state is determined by nothing but a single man and, above all, his personality ${ }^{6}$. Therefore, these individual local patriots also contributed to the creation of state power. Such people include, among others, General Edmund Taczanowski, the local hero of the present Greater Poland [Pol. "Wielkopolska"] Province. His achievements are commemorated by monuments and plaques located throughout the province ${ }^{7}$.

In the following study, we put greatest emphasis on presenting the fate of the General during the January Uprising. At that time, his participation in the uprising was the most prominent. Less attention was paid to the participation of Edmund Taczanowski in the 1848 Poznań Uprising, as his participation was less active at that time. It is worth mentioning that the description of his actions has been presented in a chronological manner, starting from an assessment of the figure of Edmund Taczanowski, then presenting his participation in the Poznań and January Uprisings. However, we decided to omit the description of his private life not related to the country's history, including General's participation in the Republican army commanded by Garibaldi in Italy. It is also worth pointing out here that the present article does not constitute a historical reconstruction and description of the entirety of course of

\footnotetext{
2 cf. F. Koneczny, Tadeusz Kościuszko: na setna rocznicę zgonu Naczelnika. Życie - czyny - duch, Warszawa 1996.

${ }^{3}$ cf. M. M. Drozdowski, Ignacy Jan Paderewski: zarys biografii politycznej, Warszawa 1986.

${ }^{4}$ cf. B. Urbankowski, Józef Pitsudski: marzyciel i strateg, Poznań 2014.

${ }^{5}$ T. Marciniak, Święci a tożsamość etniczna i lokalna, Pedagogia Christiana 2 (20)/ 2007, pp. 145-146.

${ }^{6}$ A. Kamiński, Wielka gra, Warszawa 2000, p. 21.

${ }^{7}$ http://www.choryn.archpoznan.pl/index.php/ciekawe/56-gen-edmund-taczanowski (as of 25 March 2017).
} 
events of the Greater Poland and January Uprisings. The combat actions listed are intended to serve solely as an assessment of the man himself.

\section{The patriotic activity of General Edmund Taczanowski}

At the beginning, it is worth introducing the person of General Edmund Władysław Maksymilian Taczanowski. He was born on 23 November, 1822, in Wieczyn, near Pleszew, to a landowning family bearing the Jastrzębiec coat of arms. His parents, Józef and Katarzyna, were mainly engaged in farm work. Despite this, the Taczanowski family was more than once distinguished by patriotism through the active participation of its members in independence struggles, e.g. in the relief of Vienna by King Jan III Sobieski, and in the Dąbrowski Legions ${ }^{8}$. And thus Edmund had someone to draw positive examples and learn a patriotic attitude from. He studied at artillery school, from which he graduated in 1834 with the rank of second lieutenant. He gained his first experience as a commander in the Prussian army. However, he resigned in 1846. He was admitted to the group of conspirators from Greater Poland who undertook actions aimed at provoking an uprising. Edmund Taczanowski took an active part in these preparations. He served as a courier in the south of Greater Poland region. He was arrested the same year and imprisoned in the Sonnenberg fortress in Wieniary, and then he was transferred to Berlin prison until December 1847. After his release, he returned to Greater Poland and took an active part in the 1848 Poznań Uprising. As a result of the defeat of the insurgents, he was arrested and imprisoned in Kostrzyn fortress, and later released in $1849^{9}$. Staszewski ${ }^{10}$ reports that young Edmund, wishing to continue to take active part in combat operations, decided to go to Italy, which was then struggling for independence ${ }^{11}$. There, he also fought on the Naples front and in defence of Rome under the command of Garibaldi. Unfortunately, he was taken prisoner, and he was only released once the revolution was quashed. After that, he returned to Greater Poland and was actively involved in independence activities, participating in the January Uprising. During this period, he was given the rank of general and command over a large number of troops. Once his troops were finally defeated, he decided to go to France, and from there to Turkey. He was still striving to organize Polish forces that could join the struggle for independence. Failing to receive permission to implement his plans, he returned to Poland and settled in Cracow. He returned to Greater

\footnotetext{
${ }^{8}$ Ibidem, pp. 1-2.

${ }^{9}$ A. Gąsiorowski, J. Topolski (eds.), Wielkopolski słownik biograficzny, Warszawa 1981, p. 760.

${ }^{10}$ J. Staszewski, Generat Edmund ..., op. cit., p. 18.

${ }^{11}$ In 1848 an uprising broke out, aimed at unifying Italy and liberating it from Austrian rule. Giuseppe Mazzini and Giuseppe Garibaldi took command of the uprising. (A. Chwalba, Historia powszechna: wiek XIX, Warszawa 2008, pp. 327-330).
} 
Poland after the amnesty granted by the Prussian authorities. He died on 14 September, $1879^{12}$. The General's tomb is located in the central part of the Powązi Cemetery. His remains were transferred there in 1938 from Chorynia in Greater Poland ${ }^{13}$.

\section{Participation of Edmund Taczanowski in the 1848 Poznań Uprising}

The first active participation of Edmund Taczanowski in combat operations for the Polish state took place during the Poznan Uprising, which broke out in 1848. He was then entrusted with the responsible task of commanding an artillery unit ${ }^{14}$. It was formed from a school of cadets (from the Academic Legion ${ }^{15}$ ) and was assigned to the Białoskórski camp, which was located near Pleszew. It is worth mentioning that Polish partisans were grouped only in four camps (in Września, Książ, Raszków and Pleszew), and their numbers were up to 2400 infantry and 480 horsemen ${ }^{16}$. The unit commanded by Taczanowski was supposed to act as an artillery unit, but it did not have the necessary weapons to perform such a function. Only a few sabres and pistols and no cannon were assigned to the unit. However, Taczanowski hoped that the necessary equipment and armament would soon be sent to them. Therefore, he encouraged training undertaken by gunners on a wooden model of cannon. These exercises were conducted under the command of Taczanowski, A. Kaczorowski and J. Koźmiański. Taczanowski also took care of maintaining a good atmosphere and the will to fight among soldiers. The situation changed radically when the authorities decided to suppress the uprising, and Prussian troops were sent to Greater Poland ${ }^{17}$.

The unit commanded by Edmund Taczanowski first saw combat on 25 April. At that time, he contributed to the dispersal of Prussian Cuirassiers, who attacked wounded insurgents transported from Raszków to Pleszew ${ }^{18}$. Unexpectedly, the next day his unit was surrounded by a 1,000 soldier strong Prussian unit commanded by Colonel Bonin. It is worth mentioning here that at that time Taczanowski had only a group of about 30 artillerymen, who were armed only with a few sabres and pistols, under his command. What's more, Taczanowski was obliged to refrain from fighting with his opponents. As a result, he decided

\footnotetext{
${ }^{12}$ A. Gąsiorowski, J. Topolski (eds.), Wielkopolski ..., op. cit., p. 760.

${ }^{13}$ K. Dunin-Wąsowicz, Tradycje powstania styczniowego w społeczeństwie polskim doby popowstaniowej [in:] J. Wojtasik (ed.), Powstanie styczniowe 1863-1864. Aspekty polityczne i militarne, Warszawa 1995, p. 113.

14 J. Staszewski, Generat Edmund ..., op. cit., pp. 15-16.

${ }^{15}$ B. Polak, Powstanie poznańskie 1848 r. [in:] B. Polak (ed.), Lance do boju. Szkice historyczne z dziejów jazdy wielkopolskiej X wieku - 1945 r., Poznań 1986, p. 139.

${ }^{16}$ Ibidem, p. 120.

${ }^{17}$ J. Staszewski, Generat Edmund ..., op. cit., p. 16.

${ }^{18}$ B. Polak, Powstanie poznańskie ..., op. cit., pp. 123-124.
} 
to surrender. He, and his entire unit, were treated as prisoners of war and imprisoned in Kostrzyn. After regaining freedom, he went to fight for the unification of Italy ${ }^{19}$.

\section{The activities of Edmund Taczanowski during the January Uprising}

After returning from Italy to Greater Poland, Edmund Taczanowski found himself in a country under the rule of the Russian Empire. The Polish nation was already preparing and gathering the forces required to carry out the uprising. Well aware of this, Taczanowski, already in 1861 , began to actively engage in those activities. He undertook the organization of Rifleman's Brotherhood in the Pleszew County. It aimed to spread national ideas and prepare the population for future struggle. However, after some time it was banned by Prussian authorities. Taczanowski formed the Brotherhood of Unity, which replaced the previous one, and thus also became a thorn in the side of the authorities, which attempted to close $i^{20}$.

The uprising broke out in 1863. The Działyński Committee appointed Edmund Taczanowski commander of a unit that was to be formed from volunteers from Greater Poland. Taczanowski started its organization in the vicinity of Pleszew. Unfortunately, the Russians discovered the main arsenal in the town and confiscated the weapons found. Taczanowski ordered the troops to gather in Sławoszew. The gathered insurgents were suddenly encircled by the Russian army, as a result of which they gave up or ran away without a fight. Runaways and new volunteers began to gather again in the town of Pyzdry. There, Taczanowski began to create another unit. In the end, he managed to recruit over 2,000 people. The morale of the unit was assessed positively at that time. In organizational terms, it resembled other insurgent units. It consisted of rifleman companies, scythemen and cavalry. Unlike others, it was distinguished by better armament, and in that it had artillery ${ }^{21}$. It should be noted that the subject literature assesses the Greater Poland troops, including those created under the command of Taczanowski, far better than the remaining ones (for example, Galician troops). This may be the result of the fact that, although formed in more challenging conditions, they still, in the vast majority, managed to penetrate deep into the Kingdom of Poland $^{22}$. The news of the creation of insurgent troops on the border of the Grand Duchy of Poznan led to the diversion of the Russian army there. On 29 April, near Pyzdry, the unit of Taczanowski met with the army under the command of General Brunner. Taczanowski, knowing about the enemy's upcoming forces, was able to prepare for battle earlier. His earlier

\footnotetext{
${ }^{19}$ J. Staszewski, Generat Edmund ..., op. cit., pp. 16-17.

${ }^{20}$ Ibidem, pp. 25-29.

${ }^{21}$ Ibidem, pp. 40-46.

${ }^{22}$ Z. Grabowski, Powstanie styczniowe, Warszawa 2013, p. 60.
} 
patrols gave him knowledge of the direction of approach of enemy troops. This allowed him to take a convenient position and group his forces accordingly. Initially, the battle was conducted only between riflemen. The situation changed when Taczanowski noticed some movement and weakness on the enemy side (probably due to shortage of ammunition). It was then that he decided to send scythemen and cavalry to the battlefield. The appearance of the cavalry caused the Russian commander to give the order to retreat.

Two conclusions can be drawn from this battle. First, insurgent troops were not prepared to fight the enemy. They lacked training, enthusiasm and the will to fight. Some of the soldiers remained passive, afraid to join the skirmish. Others were even unable to use their weapons. Secondly, during the battle, Taczanowski's leadership skills became more pronounced. Despite the availability of untrained soldiers, he demonstrated mastery and strategic planning skills. His regular army experience, as well as the knowledge he had acquired at artillery and engineering schools, were highlighted. He also demonstrated courage fighting in the front row with his soldiers. The victorious battle raised the morale of the army and confidence in the commanding skills of Edmund Taczanowski ${ }^{23}$.

After losing the battle, the Prussian government called for reinforcements and sent the forces towards Pyzdry again. Meanwhile, Taczanowski headed towards Kalisz. Having received the news that there was a Russian unit on their way in the town of Chocza, he decided to disperse it. Attacked by surprise, the Russians fled, suffering heavy losses. Taczanowski, on the other hand, changed the direction of his march and decided to go to the town of Rychwał and from there to Koło, where he could connect with Masovian troops. Avoiding the Russian troops stationed nearby, Taczanowski managed to reach Koło. His army was joined by new volunteers sent from Poznań region. Unfortunately, they soon received news of the upcoming enemy troops. Therefore, Taczanowski began to retreat from the city and headed towards the Mazovian units. Russian troops then took Koło and started to chase Taczanowski. It should be added that they consisted of units led by Brunner and Krasnokutski. These troops split up to attack the insurgents from two sides. However, Taczanowski knew only about the approaching army under the command of Krasnokutski. Reaching Ignacewo, he already knew that he would not succeed in escaping the Russians. Therefore, he decided to face his opponents, even though they had a considerable advantage ${ }^{24}$. Taczanowski had infantry, cavalrymen, riflemen and artillery. However, the value of artillery

\footnotetext{
${ }^{23}$ J. Staszewski, Generat Edmund ..., op. cit., pp. 50-64.

${ }^{24}$ Ibidem, pp. 50-64.
} 
was assessed as minimal, and it did not constitute an additional advantage during the battle $\mathrm{e}^{25}$. Despite the preparations made, the unit under Taczanowski failed to repel the enemy's attack. It was encircled from two sides, first by Krasnokutski's forces and then by Brunner. Unlike the battle of Pyzdry, Taczanowski's soldiers this time demonstrated their heroism. Despite their fatigue, hunger and the definite advantage of the enemy, they fought fiercely and to the very end ${ }^{26}$. Józef Piłsudski describes the battle of Ignacewo as one of the bloodiest that took place during the January Uprising. At the same time, he points out that it brought pride to our $\operatorname{army}^{27}$.

Taczanowski was rewarded for his activities. The National Government promoted him to the rank of general and gave him command of the Kalisz Voivodeship army and subsequently the Masovian Voivodeship army. Without wasting time, the General commenced combat operations in Kalisz region. He decided to convene the militia and thus fill the gaps in the ranks ${ }^{28}$. His actions and skills brought him fame, which allowed him to attract more volunteers to the army being created. As a result, he managed to form two cavalry regiments in Kalisz, which, in addition to regular uniforms, also had very good armaments. At the same time, Polak ${ }^{29}$ notes that the selection of horses in the General Taczanowski unit was one of the most beautiful. The animals came from purchase, requisition, gifts or were the private property of volunteers joining the unit. However, these horses were not prepared to participate in hostilities. "They were easily distracted by rifle and cannon shots, especially the flares used by both sides" ${ }^{30}$. The formed regiments also gave the impression that they belonged to a larger army and were not just a single unit ${ }^{31}$. The idea was to create large associations that were intended for the independent performance of combat tasks. The brigade of General Edmund Taczanowski was one of them ${ }^{32}$.

It is believed that the general waited for a long time for the start of a regular war. He avoided the enemy by changing the position of his unit from time to time. Korus notes that the insurgent forces undertook mainly defence activities and rarely offensive ones ${ }^{33}$. It wasn't

\footnotetext{
${ }^{25}$ F. L. von Erlach, Partyzantka w Polsce w roku 1863, Warszawa 1960, p. 74.

${ }^{26}$ J. Staszewski, Generał Edmund ..., op. cit., pp. 50-64.

${ }^{27}$ J. Piłsudski, Zarys historji militarnej powstania styczniowego, Przegląd historyczno-wojskowy: organ Wojskowego Biura Historycznego 1929, v. 1, book 1, p. 54.

${ }^{28}$ E. Kozłowski, M. Wrzosek, Historia oręża polskiego 1795-1939, Warszawa 1984, p. 348.

${ }^{29}$ B. Polak, W powstaniu styczniowym 1863-1864 r. [in:] B. Polak (ed.), Lance do boju ... op. cit., Poznań 1986, p. 146.

${ }^{30}$ Ibidem, p. 146.

${ }^{31}$ S. Kieniewicz, Powstanie styczniowe, Warszawa 1987, p. 60.

${ }^{32}$ B. Polak, W powstaniu styczniowym ..., op. cit., p. 149.

${ }^{33}$ C. Korus, Powstanie styczniowe w południowo-zachodnim rejonie Królestwa Polskiego [in:] J. Wojtasik (ed.), Powstanie styczniowe ... , op. cit., p. 156.
} 
until 15 August that a major clash took place near Łask. There, Taczanowski managed to destroy a Russian column commanded by Major Stepanow. Then, the General decided to get to the village of Sędziejowice. A small group of Russians also arrived there, under the command of Lt. Witmejer. Like Taczanowski, he did not expect to find enemy forces there. Being vastly outnumbered, the Russians had almost no chance to win the fight. Although the skirmish was insignificant, it had serious consequences. It provoked the mobilization of Russian forces, wishing to avenge the defeat and pursue the General ${ }^{34}$. Due to the threat of encirclement, Taczanowski tried to get to Sandomierz province. Unfortunately, he was halted and surrounded at Kruszyna. The battle was unplanned and chaotic, and the unit suffered a major defeat. The Russians did, however, celebrate a huge success in the form of the total destruction of Taczanowski's unit. The defeat at Kruszyna led to a court martial, blaming the general for failure. In December 1863, he was acquitted of the charges against him. At that time, Taczanowski was already outside the country. In order to ensure the safety of his family, he decided to settle his pregnant wife and his mother in Paris. Then, he went to Turkey to try to organize a Polish army there. However, he could not implement his plans due to the lack of consent from the National Government ${ }^{35}$.

Although the January Uprising ended in defeat, and its effects were severe for the entire nation, it became a symbol of Polish tenacity and fight for freedom. Attention is paid to individual commanders, who, due to their skills confirmed on the battlefield, gained fame and recognition. Branch traditions of units from the January Uprising were gladly taken over by some operational associations and units. In this way, the skills and merits of the General's unit were also appreciated, as its traditions were inherited by the 15 th Greater Poland Armoured Brigade $^{36}$.

\section{Summary}

Edmund Taczanowski, through his actions, demonstrated his patriotism more than once, indicating that the fate of the nation is important to him. His knowledge and skills favoured this. According to Korus ${ }^{37}$, Taczanowski was well prepared to command units consisting of various types of troops. Furthermore, he was keen to use his knowledge in practice. He was characterized by a strong desire to participate in combat operations. $\mathrm{He}$ demonstrated this in his youth, when he supported the independence movements of the

\footnotetext{
${ }^{34}$ J. Staszewski, Generat Edmund ..., op. cit., pp. 50-64.

${ }^{35}$ Ibidem, pp. 120-133.

${ }^{36}$ Z. Grabowski, Powstanie ..., op. cit. pp. 97-98.

${ }^{37}$ C. Korus, Powstanie styczniowe ..., op. cit., p.159.
} 
Greater Poland population seeking to provoke an uprising. It was then that he made contacts with a group of conspirators, who aimed to prepare them. After that, he actively participated in the outbreak of the Poznań Uprising. He was then appointed the commander of an artillery unit. Taczanowski tried to implement the entrusted tasks reliably. He also showed initiative by training the unit assigned to him and caring for its morale. Taczanowski also did not remain passive, at the time when the nation was preparing for another independence uprising against the Russian Empire. At the beginning, he undertook activities aimed at preparing the uprising, and then actively participated in it. At that time, his commanding skills were noticed. This is confirmed by the fact that, as a result of his battles, he was promoted to the rank of general. Particularly noteworthy here is the battle of Pyzdry, when, despite the numerical superiority of Russian forces, he managed to defeat his opponent. Unfortunately, personal issues forced Taczanowski to leave Poland. Nevertheless, he continued to work for the benefit of the uprising. While in Turkey, he tried to organize Polish troops to fight for independence more than once. Each time, however, he met with resistance from the National Government ${ }^{38}$.

By constantly supporting independence movements, Edmund Taczanowski undoubtedly contributed to the creation of Poland's national security in the $19^{\text {th }}$ century. His actions also proved that he was characterized by patriotism and heroism, and the benefit of the whole nation was a value he was ready to fight for. Although his activities were rather local in nature, as they focused mainly on the Greater Poland area, their significance had a national dimension. Both the actions taken during the Poznań and January Uprisings had consequences for the entire nation, and the fighting was of great importance for the success of the uprisings. The activities of General Edmund Taczanowski certainly had an impact on the fate of the uprisings. In this way, the figure of the General is an important figure in the history of the formation of Polish statehood.

${ }^{38}$ J. Staszewski, Generat Edmund ..., op. cit., pp. 16-157. 


\section{References}

Dunin-Wąsowicz K., Tradycje powstania styczniowego $w$ społeczeństwie polskim doby popowstaniowej, in: Powstanie Styczniowe 1863-1864. Aspekty Polityczne i Militarne. Warszawa 1995.

Gąsiorowski, A., Topolski, J., Wielkopolski słownik biograficzny, Warszawa 1981.

Grabowski, Z., Powstanie styczniowe, Warszawa 2013.

Kamiński, A., Wielka gra, Warszawa 2000.

Korus, C., Powstanie styczniowe w południowo-zachodnim rejonie Królestwa Polskiego, in: Powstanie Styczniowe 1983-1984. Aspekty Militarne i Polityczne. Warszawa1995.

Kozłowski, E., Wrzosek, M., Historia oręża polskiego 1795-1939, Warszawa 1984.

Marciniak, T., Święci a tożsamość etniczna i lokalna, Pedagogia Christiana, Torun 2007.

Piłsudski, J., Zarys historji militarnej powstania styczniowego. Przegląd HistorycznoWojskowy, Wojskowe Biuro Historyczne, Zakł. Graf. "Polska Zjednoczona", Warszawa 1929.

Polak, B., Powstanie poznańskie 1848 r., in: Lance Do Boju. Szkice Historyczne z Dziejów Jazdy Wielkopolskiej X Wieku - 1945 r., RSW Prasa-Książka-Ruch, Poznań 1986.

Staszewski, J., Generat Edmund Taczanowski, Poznań 1936.

von Erlach, F.L., Partyzantka w Polsce w roku 1863, Warszawa 1960. 